\title{
PENINGKATAN MOTIVASI DAN HASIL BELAJAR SISWA KELAS IV DALAM \\ PEMBELAJARAN IPS DENGAN \\ MODEL PLANTED QUESTIONS DI SD \\ NEGERI 04 TARANDAM \\ PADANG
}

\author{
Teguh Trianto ${ }^{1}$, Muhammad Sahnan ${ }^{1}$, Erwinsyah Satria ${ }^{1}$ \\ ${ }^{1}$ Program Studi Pendidikan Guru Sekolah Dasar \\ Fakultas Keguruan dan Ilmu Pendidikan \\ Universitas Bung Hatta \\ E-mail: Teguh.3anto@yahoo.co.id
}

\begin{abstract}
Abstrak
The purpose of this research is to improve students' learning motivation through the IPS model of Planted Questions in Elementary School fourth grade 04 Tarandam Padang. Types of Class Action research is research (CAR) which is implemented in two cycles. The instruments used are pieces of the implementation process of learning teacher observation, sheet student motivation, sheet final test cycle, and student motivation questionnaire sheet. Based on the analysis sheet student motivation in asking the cycle I gained an average of classical 33,33\% an increase in cycle II with an average of classical $72,22 \%$, motivation to answer in the first cycle with the average classical $41,66 \%$ increased in the second cycle with the average classical $80,55 \%$. In the motivation questionnaire in the first cycle gained an average $55.89 \%$ increase in the classical second cycle average classical $79,51 \%$. The results of the first cycle of learning gained an average of 63,88 increased in the second cycle of 71,94. From the results obtained can be concluded that there is an increased motivation to learn social studies fourth grade students of SD Negeri 04 Padang Tarandam Planted Questions after using the model.
\end{abstract}

\section{Keywords: Motivation, Learning Outcomes, and Model Planted Questions.}

\section{Pendahuluan}

Secara umum pendidikan merupakan suatu bagian yang tidak ada akhirnya dan berlangsung seumur hidup. Pendidikan yang diterima seseorang pada masa kecil pasti akan berpengaruh terhadap kehidupan di masa yang akan datang, begitu juga dengan pendidikan di lembaga-lembaga formal lainnya. Kemampuan belajar yang dimiliki di Sekolah Dasar (SD) merupakan bekal pokok yang akan dibawa ke jenjang pendidikan yang lebih tinggi.
Pendidikan merupakan suatu usaha untuk membangun manusia seutuhnya yang berkualitas sesuai yang diinginkan, sedangkan proses pembelajaran merupakan inti dari pendidikan secara keseluruhan. Pembelajaran memiliki tujuan untuk mengembangkan pengetahuan, sikap, dan keterampilan dasar yang diperlukan peserta didik dalam kehidupan. Tenaga pendidik memiliki peranan penting dalam pencapaian tujuan tersebut. 
Berdasarkan hasil observasi yang peneliti lakukan pada hari Senin tangal 9 September 2013 dan pada saat peneliti melakukan praktek lapangan kependidikan di kelas IV SD Negeri 04 Tarandam, diketahui bahwasanya motivasi siswa pada pembelajaran IPS rendah, hal ini terlihat degan tercapai indikator, diantaranya 18 siswa hanya 6 orang $(33,33 \%)$ yang mau bertanya pada saat pembelajaran dan hanya 8 orang $(44,44 \%)$ yang berani menjawab pertanyaan yang diajukan guru. setelah diamati banyak siswa yang tidak mengerti dengan materi yang diberikan guru, sehingga pada saat pembelajaran berlangsung suasana menjadi pasif dikarenakan motivasi siswa dalam bertanya, menjawab pertanyaan masih rendah, selain itu metode yang sering digunakan guru adalah metode tanya jawab dan metode ceramah, tetapi dominan metode ceramah yang mana metode ceramah ini jika dilakukan terus menerus tanpa variasi terkadang membuat siswa menjadi bosan dalam menerima materi pelajaran, mereka lebih memilih untuk ngobrol, bermain dan keluar masuk kelas sehingga pemebalajaran terlihat pasif.

Berdasarkan hasil wawancara yang peneliti lakukan dengan ibu Afryarty selaku guru kelas IV di SD Negeri 04 Tarandam pada tanggal 24 September 2013 dimana salah satu faktor yang menyebabkan kelas menjadi pasif pada saat pembelajaran adalah karena metode yang digunakan adalah metode ceramah dan metode tanya jawab tetapi lebih dominan menggunakan metode ceramah, dan motivasi siswa dalam bertanya, menjawab pertanyaan dan hasil belajar yang diperoleh pun menunjukan bahwa hasilnya tidak memuaskan, hal ini dapat dilihat dari nilai rata-rata hasil Ulangan Harian IPS siswa adalah 64,44 dengan persentase ketuntasan 55,56 \% dari 18 siswa. Hal ini dapat menjadi bukti, bahwa masih banyak siswa mendapat nilai dibawah Kriteria ketuntasan Minimum (KKM) yang telah ditetapkan oleh sekolah SD Negeri 04 Tarandam. Dari 18 orang peserta didik yang nilainya tuntas hanya10 Orang $(55,56 \%)$ siswa.

Dari uraian tersebut dapat diketahui bahwasanya motivasi siswa dalam bertanya dan menjawab pertanyaan masih rendah, oleh karena itu peneliti memiliki solusi terhadap permasalahan tersebut yaitu dengan menggunakan model Planted Questions. Menurut Istarani (2011:209), "model Planted Qustions merupakan model yang dapat membantu memberikan informasi dalam bentuk respon terhadap pertanyaan yang telah ditanamkan /diberikan sebelumnya kepada peserta didik tertentu". Karena dengan model ini siswa akan mendapatkan informasi dalam bentuk respon terhadap pertanyaan, karena sebelum memulai pembelajaran guru 
memilih beberapa siswa sebagai penanya yaitu dengan memberikan potongan kertas yang berisi pertanyaan dan isyarat untuk mengajukan pertanyaan, guru menjelaskan petujuk kapan siswa akan mengajukan pertanyaan kepada guru, pada saat pembelajaran guru memberikan isyarat pertanyaan pertama dan siswa yang mendapat isyarat pertama maka siswa tersebut mengajukan pertanyaan begitu seterusnya sampai isyarat yang diberikan guru habis, kemudian guru membuka sesi Tanya jawab diluar pertanyaan yang telah di susun tersebut. Dengan menggunakan model Planted Questions diharapkan dapat mengatasi permasalahan yang terjadi di SD Negeri 04 Tarandam Padang dan mampu meningkatkan motivasi dan hasil belajar siswa sehingga proses Pembelajaran dapat menjadi lebih menarik.

Berdasarkan uraian permasalahan di atas, tujuan penelitian ini adalah untuk "Meningkatan Motivasi dan Hasil Belajar Siswa Kelas IV Dalam Pembelajaran IPS Dengan Model Planted Questions di SD Negeri 04 Tarandam Padang."

\section{Metodologi Penelitian}

Jenis penelitian yang digunakan penelitian adalah penelitian tindakan kelas (PTK). Wardani, dkk (2008:14), menyatakan "PTK adalah penelitian yang dilakukan oleh guru di dalam kelasnya sendiri melalui refleksi diri, dengan tujuan untuk memperbaiki kinerjanya sebagai seorang guru sehingga hasil belajar siswa meningkat', Sementara itu Arikunto, dkk (2010:104), mendefenisikan "PTK merupakan suatu penelitian yang akar pemasalahan muncul di kelas, dan dirasakan langsung oleh guru yang bersangkutan sehingga sulit dibenarkan jika anggapan bahwa permasalahan dalam PTK diperoleh dari persepsi atau lamunan seseorang peneliti'’.

PTK dilaksanakan dengan metode siklus, satu siklus $2 \mathrm{x}$ pertemuan terdari dari empat komponen yaitu perancanaan (planning) berisi tentang tujuan atau kompetensi yang harus tercapai serta perlakuan khusus yang akan dilakukan oleh guru dalam proses pembelajaran; tindakan (acting) adalah perlakuan yang dilakasanakan oleh guru berdasarkan perencananaan yang telah disusun; pengamatan (observing) dilakukan untuk mengumpulkan informasi tentang proses pembelajaran yang dilakukan guru dengan tindakan yang telah disusun; dan refleksi (reflecting) aktivitas melihat berbagai kekurangan yang dilaksanakan guru selama tindakan.

Penelitian tindakan kelas ini dilaksanakan di kelas IV SD Negeri 04 Tarandam Padang, RT III, RW 03, Kelurahan Sawahan, Kecamatan Padang Timur.

Subjek penelitian ini adalah siswa kelas IV SD Negeri 04 Tarandam. 
Siswanya berjumlah 18 orang, 8 orang laki-laki dan 10 orang perempuan.

Waktu penelitian ini dilaksanakan pada semester genap tahun ajaran 2013/2014, terhitung dari waktu perencanaan sampai penulisan laporan hasil penelitian di SD Negeri 04 Tarandam Padang. Sedangkan pelaksanaan tindakan siklus I dimulai tanggal 21 Januari sampai tanggal I Februari dan siklus II dimulai tanggal 4 Februari sampai 18 Februari 2014.

Indikator keberhasilan motivasi dan proses pembelajaran yang peneliti ingin tingkatkan mengacu pada standar Kriteria Ketuntasan Minimal (KKM) yang ditetapkan oleh sekolah atau 70 dan indikator keberhasilan motivasi siswa yaitu $70 \%$ atau lebih.

Dalam penelitian ini, peneliti menggunakan beberapa instrument penelitian untuk mengumpulkan data:

1. Lembar observasi proses pelaksanaan pembelajaran guru, observer mengamati setiap aktivitas yang dilakukan oleh guru pada saat kegiatan pembelajaran berlangsung. Mulai dari awal, kegiata inti, pengelolaan kelas, hingga kegiatan penutup. Observer akan mengamati apakah guru telah mengajar sesuai dengan RPP yang telah dibuat sebelumnya.

2. Lembar observasi motivasi siswa, lembar ini digunakan untuk melihat motivasi siswa secara keseluruhan dalam setiap kali pertemuan, dengan cara memberikan ceklis pada setiap aspek yang diamati dalam satu kali pertemuan

3. Lembar tes akhir siklus, Hasil belajar dapat dilihat melalui tes yang diberikan kepada siswa. Dan tes yang dilakukan, nantinya akan terlihat apakah kriteria ketuntasan yang ditargetkan oleh guru sudah dicapai oleh siswa atau belum.

4. Lembar angket motivasi siswa, Angket adalah teknik pengumpulan data dengan cara mengajukan daftar pertanyaan atau pernyataan untuk diisi oleh responden.

Teknik analisis data yang digunakan untuk mengumpulkan data adalah data analisis observasi keberhasilan mengajar guru, data analisis motivasi siswa, data analisis hasil belajar dan data analisis angket motivasi siswa.

\section{Hasil Penelitian dan Pembahasan}

Dalam penelitian ini dilakukan 2 siklus. Siklus pertama pada penelitian ini dilaksanakan pada hari selasa tanggal 21 Januari pukul 07.30-09.30 WIB dan hari selasa 28 Januari pukul 07.30-09.30 WIB, tes dilaksanakan pada hari sabtu tanggal 1 Februari pukul 10.30-12.05 WIB. Sedangkan siklus ke dua dilaksanakan pada hari selasa tanggal 4 Februari pukul 07.30-09.30 wib dan 11 Februari pukul 07.30-09.30 WIB, tes dilaksanakan pada 
hari selasa tanggal 18 Februari pukul 07.30-09.30 WIB. Hasil data penelitian ini berupa peningkatan motivasi pembelajaran IPS Siswa. Penelitian ini berbentuk penelitian tindakan kelas yang bekerjasama dengan guru kelas.

\section{Deskripsi Kegiatan Pembelajaran Siklus I}

\section{1) Data Observasi Aspek Guru}

Tabel 2. Rekapitulasi Hasil Pengamatan Terhadap Guru Pada Siklus I

\begin{tabular}{|c|c|c|c|}
\hline Pertemuan & $\begin{array}{c}\text { Jumlah } \\
\text { Skor }\end{array}$ & Persentase & Kategori \\
\hline 1 & 29 & $72,5 \%$ & $\begin{array}{c}\text { Cukup } \\
\text { baik }\end{array}$ \\
\hline 2 & 30 & $75 \%$ & $\begin{array}{c}\text { Cukup } \\
\text { baik }\end{array}$ \\
\hline Rata-rata klasikal & $73,75 \%$ & $\begin{array}{c}\text { Cukup } \\
\text { baik }\end{array}$ \\
\hline
\end{tabular}

Pada Tabel 2 rekapitulasi hasil pengamatan terhadap guru pada siklus I diperoleh fakta bahwa dalam penerapan model pembelajaran Planted Questions dalam pembelajaran IPS pada pertemuan pertama $72,5 \%$ dalam pengamatan guru mendapat nilai cukup baik. Pertemuan kedua $75 \%$ mendapat nilai cukup baik. dengan rata-rata73,75 \% kriteria dalam pengamatan guru mendapatkan nilai cukup baik.

\section{2) Rekapituliasi Hasil Pengamatan Motivasi Siswa}

Tabel 3. Rekapituliasi Hasil Pengamatan Motivasi Siswa Pada Sikus I

\begin{tabular}{|c|c|c|c|c|c|}
\hline \multirow[b]{2}{*}{$\begin{array}{l}\mathrm{N} \\
\mathrm{o}\end{array}$} & \multirow[b]{2}{*}{$\begin{array}{c}\text { Aspek Motivasi } \\
\text { Yang Diamati }\end{array}$} & \multicolumn{2}{|c|}{ SIKLUS I } & \multirow[b]{2}{*}{$\begin{array}{l}\text { Rata } \\
\text {-rata }\end{array}$} & \multirow[b]{2}{*}{$\begin{array}{l}\text { Keterang } \\
\text { an }\end{array}$} \\
\hline & & $\begin{array}{c}\text { Perte } \\
\text { muan } \\
1 \\
\end{array}$ & $\begin{array}{c}\text { Perte } \\
\text { muan } \\
2 \\
\end{array}$ & & \\
\hline 1 & Bertanya & $\begin{array}{c}33,33 \\
\% \\
\end{array}$ & $\begin{array}{c}33,33 \\
\% \\
\end{array}$ & $\begin{array}{l}33,3 \\
3 \% \\
\end{array}$ & $\begin{array}{l}\text { Sangat } \\
\text { rendah }\end{array}$ \\
\hline 2 & $\begin{array}{l}\text { Menja } \\
\text { wab } \\
\text { pertan } \\
\text { yaan }\end{array}$ & $\begin{array}{c}38,88 \\
\%\end{array}$ & $\begin{array}{c}44,44 \\
\%\end{array}$ & $\begin{array}{l}41,6 \\
6 \%\end{array}$ & $\begin{array}{l}\text { Sangat } \\
\text { rendah }\end{array}$ \\
\hline & Rata-rata klasikal & $\begin{array}{c}36,10 \\
5 \%\end{array}$ & $\begin{array}{c}38,88 \\
5 \%\end{array}$ & $\begin{array}{l}37,4 \\
95 \%\end{array}$ & $\begin{array}{l}\text { Sang } \\
\text { at } \\
\text { rend } \\
\text { ah }\end{array}$ \\
\hline
\end{tabular}

Berdasarkan data yang tertera pada Tabel 3 rekapitulasi hasil pengamatan motivasi siswa pada siklus I dapat dikemukakan persentase rekapitulasi pengamatan motivasi siswa dalam pembelajaran IPS dan penjelasannya sebagai berikut:

1. Persentase rata-rata klasikal siswa bertanya pada guru adalah 33,33\%, artinya berdasarkan kriteria yang diterapkan skor tersebut berada pada rentangan skor $\leq 70 \%$ sehingga penerapan model pembelajaran Planted Questions pada siklus 1 termasuk ke dalam kriteria sagat rendah.

2. Persentase rata-rata klasikal siswa yang menjawab dan menaggapi pertanyaan adalah $41,66 \%$, artinya berdasarkan kriteria yang ditetapkan skor tersebut adalah berada pada rentang skor $\leq 70 \%$ sehingga penerapan model 
pembelajaran Planted Questions pada siklus 1 ini termasuk ke dalam kriteria sangat rendah.

3) Data Hasil Belajar Pada tes akhir Siklus I

Tabel 4. Ketuntasan dan Rata-Rata Hasil Belajar Siswa pada Siklus I

\begin{tabular}{|l|c|}
\hline \multicolumn{1}{|c|}{ Uraian } & Jumlah \\
\hline Jumlah Siswa yang mengikuti tes & 18 \\
\hline Jumlah Siswa yang tuntas tes & 7 \\
\hline Jumlah Siswa yang tidak tuntas & 11 \\
tes & \\
\hline Persentase ketuntasan tes & $38,89 \%$ \\
\hline Rata-rata nilai tes & 63,88 \\
\hline
\end{tabular}

Ternyata setelah diberikan evaluasi diperoleh 11 orang siswa yang mendapat nilai dibawah KKM dan 7 orang siswa yang tuntas, adapun KKM yang ditetapkan pada pembelajaran IPS ini yaitu 70. Untuk itu dapat dilihat rekapitulasi nilai ketuntasan siswa pada tabel 5. Dari tabel 5 dapat dilihat 18 orang siswa yang mengikuti tes dengan nilai rata-rata tes 63,88 , yang terdiri dari $38,89 \%$ siswa yang tuntas dan $61,11 \%$ siswa yang belum tuntas.

\section{4) Rekapitulasi Hasil Angket Motivasi}

Tabel 5. Rekapitulasi Hasil Angket Motivasi Belajar Siswa Pada Siklus I

\begin{tabular}{|c|c|c|c|}
\hline \multirow{2}{*}{ No } & \multirow{2}{*}{ Angket Motivasi } & Persentase & \multirow{2}{*}{ kategori } \\
\cline { 3 - 3 } & Siswa & Siklus I & \\
\hline 1 & Keinginan untuk & $55,89 \%$ & Motivasi siswa \\
& memperoleh & & cukup \\
\hline & pengetahuan & & \\
\hline
\end{tabular}

Berdasarkan data yang terdapat pada Tabel 5 rekapitulasi hasil angket motivasi belajar siswa pada siklus I memperoleh rata-rata $55,89 \%$, artinya berdasarkan kriteria yang diterapkan skor tersebut berada pada rentangan skor $\leq 70 \%$ sehingga penerapan model pembelajaran Planted Questions pada siklus 1 termasuk ke dalam Kriteria motivasi siswa cukup.

\section{Deskripsi Kegiatan Pembelajaran Siklus II \\ 1) Data Hasil Observasi Aspek Guru Siklus II}

Tabel 6. Rekapitulasi Hasil Pengamatan Terhadap Guru Pada Siklus II

\begin{tabular}{|c|c|c|c|}
\hline $\begin{array}{c}\text { Pertemu } \\
\text { an }\end{array}$ & $\begin{array}{c}\text { Jumlah } \\
\text { Skor }\end{array}$ & Persentase & Keterangan \\
\hline 1 & 30 & $75 \%$ & Cukup baik \\
\hline 2 & 32 & $80 \%$ & Baik \\
\hline \multicolumn{2}{|c|}{ Rata-rata klasikal } & 77,5 & Baik \\
\hline
\end{tabular}

Pada Tabel 6 rekapitulasi hasil pengamatan terhadap guru pada siklus II diperoleh fakta bahwa dalam penerapan 
model pembelajaran Planted Questions dalam pembelajaran IPS pada siklus II persentase pertemuan pertama $75 \%$ dan pertemuan kedua 80\%. Dapat disimpulkan kriteria dalam pengamatan guru mendapatkan nilai baik dengan rata-rata $77,5 \%$. Sedangkan pada siklus I dalam aspek pengamatan guru $73,75 \%$ dengan rata-rata mendapatkan nilai cukup baik.

\section{2) Rekapituliasi Hasil Pengamatan Motivasi Siswa}

Tabel 7. Rekapituliasi Hasil Pengamatan Motivasi Siswa Pada Sikus II

\begin{tabular}{|c|c|c|c|c|c|}
\hline \multirow[b]{2}{*}{ No } & \multirow[b]{2}{*}{$\begin{array}{l}\text { Aspek } \\
\text { Yang } \\
\text { Diamati }\end{array}$} & \multicolumn{2}{|c|}{ SIKLUS II } & \multirow[b]{2}{*}{$\begin{array}{l}\text { Rata- } \\
\text { rata }\end{array}$} & \multirow[b]{2}{*}{$\begin{array}{l}\text { Katego } \\
\text { ri }\end{array}$} \\
\hline & & $\begin{array}{c}\text { Perte } \\
\text { muan } \\
1\end{array}$ & $\begin{array}{c}\text { Perte } \\
\text { muan } \\
2\end{array}$ & & \\
\hline 1. & $\begin{array}{l}\text { Bertanya } \\
\text { pada guru }\end{array}$ & $\begin{array}{c}66,67 \\
\%\end{array}$ & $\begin{array}{c}77,78 \\
\%\end{array}$ & $72,22 \%$ & Tinggi \\
\hline 2. & $\begin{array}{l}\text { Menjawab } \\
\text { pertanyaan }\end{array}$ & $\begin{array}{c}77,78 \\
\%\end{array}$ & $\begin{array}{c}83,33 \\
\%\end{array}$ & $80,55 \%$ & Tinggi \\
\hline \multicolumn{2}{|c|}{ Rata-rata klasikal } & $\begin{array}{c}72,22 \\
\%\end{array}$ & $\begin{array}{c}80,55 \\
\%\end{array}$ & $76,38 \%$ & Tinggi \\
\hline
\end{tabular}

Berdasarkan data yang tertera pada

Tabel 7 rekapitulasi hasil pengamatan motivasi siswa pada siklus II dalam pembelajaran IPS pada bagian yang diamati dan penjelasannya sebagai berikut:

1. Persentase rata-rata klasikal siswa bertanya pada guru adalah 72,22\%, artinya berdasarkan kriteria yang diterapkan skor tersebut berada pada rentangan skor $65 \%-80 \%$ sehingga penerapan model pembelajaran Planted Questions pada siklus II termasuk ke dalam kriteria Tinggi.

2. Persentase rata-rata klasikal siswa yang menjawab dan menaggapi pertanyaan adalah $80,55 \%$, artinya berdasarkan kriteria yang ditetapkan skor tersebut adalah berada pada rentang skor $65 \%$ $80 \%$ sehingga penerapan model pembelajaran Planted Questions pada siklus II ini termasuk ke dalam kriteria Tinggi.

\section{3) Data Hasil Belajar}

Pada siklus I hasil belajar siswa memperoleh rata-rata $63,88 \%$ berarti hasil belajar siswa berada pada kriteria cukup baik. Dari tabel 8 dapat dilihat 18 orang siswa yang mengikuti tes dengan nilai ratarata tes 71,94 yang terdiri dari $77,78 \%$ siswa yang tuntas dan 22,22\% siswa yang belum tuntas. Berikut rekapitulasi hasil belajar siswa pada siklus II dapat dilihat pada Tabel 8.

Tabel 8. Ketuntasan dan Rata-Rata Hasil Belajar Siswa pada Siklus II.

\begin{tabular}{|l|c|}
\hline \multicolumn{1}{|c|}{ Uraian } & Jumlah \\
\hline Jumlah Siswa yang mengikuti tes & 18 \\
\hline Jumlah Siswa yang tuntas tes & 14 \\
\hline Jumlah Siswa yang tidak tuntas tes & 4 \\
\hline Persentase ketuntasan tes & $77,78 \%$ \\
\hline Rata-rata nilai tes & 71,94 \\
\hline
\end{tabular}




\section{4) Rekapitulasi Hasil Angket Motivasi}

Tabel 9. Rekapitulasi Hasil Angket Motivasi Pada Siklus II

\begin{tabular}{|c|c|c|c|}
\hline \multirow[t]{2}{*}{ No } & \multirow{2}{*}{$\begin{array}{c}\text { Angket } \\
\text { Motivasi } \\
\text { Siswa }\end{array}$} & \multicolumn{2}{|c|}{ Persentase skor } \\
\hline & & Siklus I & Siklus II \\
\hline 1 & $\begin{array}{l}\text { Keinginan } \\
\text { untuk } \\
\text { memperoleh } \\
\text { pengetahuan }\end{array}$ & $55,89 \%$ & $79,51 \%$ \\
\hline & kategori & $\begin{array}{c}\text { Motivasi siswa } \\
\text { cukup }\end{array}$ & $\begin{array}{c}\text { Motivasi siswa } \\
\text { tinggi }\end{array}$ \\
\hline
\end{tabular}

Dari rekapitulasi nilai angket pada tabel 9 dapat dikatakan bahwa motivasi belajar siswa meningkat jika dibandingkan pada siklus I. Pada siklus I rata-rata angket motivasi siswa dengan menggunakan model Planted Questions yaitu 55,89\% sedangkan pada siklus II diperoleh $79,51 \%$. Berdasarkan data yang terdapat pada Tabel 9 rekapitulasi hasil angket motivasi belajar siswa pada siklus II memperoleh rata-rata $79,51 \%$, artinya berdasarkan kriteria yang diterapkan skor tersebut berada pada rentangan skor $\geq 70 \%$ sehingga penerapan model pembelajaran Planted Questions pada siklus II termasuk ke dalam kriteria motivasi siswa tinggi.

\section{Pembahasan}

Penelitian tindakan kelas melalui model pembelajaran Planted Questions terdiri dari dua siklus yang setiap siklusnya terdiri dari 2 kali pertemuan dan 1 kali tes hasil belajar pada setiap akhir siklus. Penelitian ini menggunakan instrumen penelitian berupa lembar observasi proses pelaksanaan pembelajaran guru, lembar motivasi siswa dan lembar angket motivasi siswa, lembar tes akhir siklus.

Pelaksanaan pada siklus I terdapat masalah pada indikator motivasi siswa yaitu kurangnya siswa yang bertanya pada guru, siswa kurang termotivasi untuk bertanya dkarenakan timbulnya masalah dari guru, seperti: guru terlalu cepat menjelaskan materi pelajaran, siswa kurang terfokus dengan pembelajaran, guru kurang memberikan penguatan. Untuk itu guru memberikan perbaikan pada masalah tersebut. Setelah guru merefleksi diri, guru dan observer berkolaborasi. Pada siklus II guru telah melakukan perbaikan masalah yang terjadi pada siklus I. pada saat melaksanakan proses pembelajaran pada siklus I siswa kurang focus pada pembelajaran, sehingga siswa sedikit yang bertanya pada guru. Guru menekankan kepada siswa agar tidak ribut, dan memberi sangsi kepada siswa yang rebut tujuannya agar siswa focus pada pembelajaran. Sehingga proses pembelajaran terlaksana dengan baik. Ini ditandai adanya peningkatan motivasi bertanya siswa pada siklus I dilihat dari rata-rata klasikal $33,33 \%$ mengalami peningkatan ke siklus II dengan rata-rata klasikal 72,22\%.

Pelaksanaan pembelajaran pada siklus I dilakukan selama dua kali pertemuan yaitu pertemuan I dilaksanakan 
pada tanggal 21 Januari 2014, pertemuan II 28 Januari 2014, dengan waktu 2x35 menit untuk setiap kali pertemuan. Sedangkan pelaksanaan pembelajaran pada siklus II dilakukan selama dua kali pertemuan yaitu pertemuan 1 dilaksanakan pada tanggal 04 Februari 2014, pertemuan 2 dilaksanakan 11 Februari 2014, dengan waktu 2x35 menit setiap kali pertemuan. Proses pembelajaran setiap kali pertemuan mengacu pada Buku Buku IPS SD Kelas IV. Pembelajaran melalui model pembelajaran Planted Questions membuat siswa merasa senang dalam belajar terutama siswa yang aktif dalam proses pembelajaran. Dengan model Planted Questions membuat siswa berani untuk menyampaikan sesuatu di depan temantemannya.

\section{1) Pelaksanaan Pembelajaran oleh Guru}

Tabel 10. Persentase Pelaksanaan Pembelajaran oleh Guru melalui model Planted Questions pada Siklus I dan Siklus II.

\begin{tabular}{|c|c|c|}
\hline \multirow{2}{*}{ Pertemuan } & \multicolumn{2}{|c|}{ Siklus } \\
\cline { 2 - 3 } & I & II \\
\hline 1 & $72,5 \%$ & $75 \%$ \\
\hline 2 & $75 \%$ & $80 \%$ \\
\hline Rata-rata & $73,75 \%$ & 77.5 \\
\hline Kategori & Cukub baik & baik \\
\hline
\end{tabular}

Dari Tabel 10 persentase pelaksanaan pembelajaran oleh guru melalui model Planted Questions dapat disimpulkan bahwa pelaksanaan pembelajaran melalui Planted Questions dapat meningkatkan pelaksanaan pembelajaran aspek guru. Hal ini terlihat adanya peningkatan rata-rata persentase pelaksanaan pembelajaran oleh guru dari siklus I dengan rata-rata $73,7475 \%$ mengalami peningkatan ke siklus II dengan rata-rata $79,99 \%$. Peningkatan pelaksanaan pembelajaran oleh guru disebabkan guru sudah bisa melaksanakan pembelajaran IPS melalui model pembelajaran Planted Questions.

\section{2) Motivasi Belajar Siswa dalam Pembelajaran IPS}

Tabel 11. Persentase Rata-rata Motivasi Siswa dalam Pembelajaran pada Siklus I dan Siklus II

\begin{tabular}{|c|c|c|c|}
\hline \multirow{2}{*}{ No } & \multirow{2}{*}{$\begin{array}{c}\text { Indikator Motivasi } \\
\text { Siswa }\end{array}$} & \multicolumn{2}{|c|}{ Rata-rata Persentase } \\
\cline { 3 - 4 } & Siklus I & Siklus II \\
\hline 2 & Bertanya pada guru & $33,33 \%$ & $72,22 \%$ \\
\hline 2 & Menjawab pertanyaan & $41,66 \%$ & $80,55 \%$ \\
\hline \multirow{2}{*}{ Rata-rata Klasikal } & 37,495 & 76,38 \\
\hline \multicolumn{2}{|c|}{ Kategori } & Rendah & Tinggi \\
\hline
\end{tabular}

Berdasarkan Tabel 11 persentase rata-rata motivasi siswa dalam pembelajaran pada siklus I dan II, dapat disimpulkan bahwa pembelajaran IPS dengan menggunakan model pembelajaran Planted Questions di kelas IV dapat 
meningkatkan motivasi siswa dalam proses pelaksanaan pembelajaran IPS.

a. Keterlibatan siswa bertanya pada guru dalam pelajaran IPS dengan menggunakan Model pembelajaran Planted Questions di kelas IV pada siklus I dengan rata-rata $33,33 \%$ mengalami penigkatan ke siklus II dengan rata-rata $72,22 \%$.

b. Keterlibatan siswa aktif dalam menjawab pertanyaan guru dalam pembelajaran IPS dengan menggunakan model pembelajaran Planted Questions di kelas IV pada siklus I dengan rata-rata $41,66 \%$ mengalami penigkatan ke siklus II dengan rata-rata $80,55 \%$.

Rata-rata motivasi siswa secara klasikal pada siklus I adalah 37,495\% mengalami peningkatan ke siklus II ratarata klasikal 76,38\%. Peningkatan motivasi siswa disebabkan pada pembelajaran IPS menggunakan model pembelajaran Planted Questions dalam proses pelaksanaan pembelajaran Guru sudah baik.

\section{3) Hasil Belajar}

Tabel 12. Persentase Ketuntasan Hasil Belajar Siklus I dan Siklus II

\begin{tabular}{|c|c|c|c|}
\hline Siklus & $\begin{array}{c}\text { Persentase dan } \\
\text { Jumlah Siswa yang } \\
\text { Telah Mencapai } \\
\text { Nilai } \geq 70\end{array}$ & $\begin{array}{c}\text { Persentase dan } \\
\text { Jumlah Siswa yang } \\
\text { Belum Mencapai } \\
\text { Nilai } \geq 70\end{array}$ & $\begin{array}{c}\text { Rata- } \\
\text { rata } \\
\text { nila } \\
\text { tes }\end{array}$ \\
\hline Siklus I & $38,89 \%$ (7 orang) & $61,11 \%$ (11 orang) & 63,88 \\
\hline Siklus II & $77,78 \%$ (14 orang) & $22,22 \%$ (4 orang) & 71,94 \\
\hline
\end{tabular}

Berdasarkan Tabel 12 di atas, tentang hasil belajar siswa dalam 2 siklus, terlihat bahwa pada siklus I, siswa yang tuntas belajar 38,89\% dan yang belum

tuntas belajar $61,11 \%$. Sedangkan pada siklus II, siswa yang tuntas belajar $77,77 \%$ dan yang belum tuntas belajar hanya $22,22 \%$. Sedangkan untuk nilai ratarata hasil belajar secara klasikal juga mengalami peningkatan dan sudah mencapai standar nilai KKM.

\section{4) Angket Motivasi Belajar Siswa dalam Pembelajaran IPS}

Tabel 13. Persentase Rata-rata Angket Motivasi Siswa dalam Pembelajaran IPS pada Siklus I dan Siklus II

\begin{tabular}{|c|c|c|c|}
\hline \multirow{2}{*}{ No } & \multicolumn{2}{|c|}{ Rata-rata Persentase } & \multirow{2}{*}{$\%$ Kenaikan } \\
\cline { 2 - 3 } & Siklus I & Siklus II & \multirow{2}{*}{$23,62 \%$} \\
\hline 1 & $55,89 \%$ & $79,51 \%$ & \\
\hline Kategori & Cukup & Tinggi & \\
\hline
\end{tabular}

Berdasarkan Tabel 13 persentase rata-rata angket motivasi siswa dalam pembelajaran IPS pada siklus I dan II, dapat disimpulkan bahwa pembelajaran IPS melalui melalui model pembelajaran Planted Questions yang dilaksanakan dapat meningkatkan motivasi siswa dalam proses pelaksanaan pembelajaran IPS. Rata-rata angket motivasi siswa secara klasikal pada siklus I adalah 55,89\% mengalami peningkatan ke siklus II 
79,51\%. Peningkatan motivasi siswa disebabkan pada pembelajaran IPS menggunakan Model pembelajaran Planted Questions.

\section{Kesimpulan}

Berdasarkan hasil penelitian yang diperoleh, maka dapat disimpulkan sebagai berikut:

1. Peningkatan motivasi siswa dalam bertanya pada pembelajaran IPS dengan model Planted Questions di SD Negeri 04 Tarandam Padang. Siklus I dengan rata-rata klasikal 33,33\% meningkat ke siklus II rata-rata klasikal $72,22 \%$.

2. Peningkatan motivasi siswa dalam menjawab pertanyaan pada pembelajaran IPS dengan model Planted Questions di SD Negeri 04 Tarandam Padang. Siklus I dengan rata-rata klasikal 41,66\% meningkat ke siklus II dengan rata-rata klasikal $80,55 \%$.

3. Peningktan Hasil belajar pada aspek kognitif (pemahaman/C2) dalam pembelajaran IPS dengan model Planted Questions di SD Negeri 04 Tarandam Padang. Rata-rata nilai tes akhir siklus siswa pada siklus I 63,88 meningkat ke siklus II dengan rata-rata nilai tes akhir siklus 71,94 .

\section{Daftar Pustaka}

Arikunto, Suharsimi, Suhardjono dan Supardi. 2010. Penelitian Tindakan Kelas. Jakarta: Bumi Aksara.

BSNP. 2006. Kurikulum Tingkat Satuan Pendidikan (KTSP). Jakarta: BSNP.

Desfitri, Rita, Zulfa Amrina, Wince Hendri, Nuryasni dan Netriwati. 2008. "Peningkatan Aktivitas, Motivasi dan Hasil Belajar Matematika Siswa Kelas VIII2 MTSN Model Padang Melalui Pendekatan Kontekstual". Laporan Pengembangan Inovasi Pembelajaran di Sekolah (PIPS). Padang: FKIP Universitas Bung Hatta.

Hamalik, Oemar. 2007. Kurikulum dan Pembelajaran. Jakarta: Bumi Aksara.

------ 2012. Proses Belajar Mengajar. Jakarta: Bumi Aksara.

Istarani. 2012. 58 Model Pembelajaran Inovatif. Medan: Media Persada.

Novia, Wira. 2012. "Pengaruh Strategi Planted Qustions Terhadap Aktivitas Siswa Pada Pendidikan Kewarganegaraan Di SMPN 1 Spora". Skripsi. Padang: Universitas Bung Hatta.

Pebriyenni. 2009. Pembelajaran IPS II (Kelas Tinggi). Padang: Kerjasama Dikti- Depdiknas dan Jurusan PGSD FKIP Universitas Bung Hatta.

Sapriya, Dadang Sundawa, Iim Siti Masyitoh. 2006. Pembelajaran Dan Evaluasi Hasil Belajar IPS. Padang: UPI Press. 
Sardiman, AM. 2012. Interaksi dan Motivasi Belajar Mengajar. Jakarta: Raja Grafindo Persada.

Silberman, Melvin L. 2009. Aktive Learning $101 \quad$ Strategi Pembelajaran Aktiv. Yogyakarta: Pustaka Insan Madani dan Yappendis.

Sudjana, Nana. 2009. Penilaian Hasil Proses Belajar Mengajar. Bandung: Remaja Rosdakarya.

Suprijono, Agus. 2010. Cooperative Learning Teori dan Aplikasi Paikem. Yogyakarta: Pustaka Belajar

Uno, Hamzah B . 2007. Teori Motivasi dan Pengukurannya. Jakarta: Bumi Aksara.
------ 2012. Teori Motivasi dan Pengukurannya. Jakarta: Bumi Aksara.

Wahyuni, Sri. 2006. "Pengaruh Penerapan Strategi Planted Qustions terhadap Hasil Belajar Pada Pendidikan Geografi di SMPN 2 Bayang". Skripsi. Padang: STKIP

Wardani, IGAK dan Kuswaya Wihardit. 2008. Penelitian Tindakan Kelas. Jakarta: Universitas Terbuka.

Warsita, Bambang. 2008. Teknologi Pembelajaran Landasan dan Aplikasinya. Jakarta: Rineka Cipta. 